\title{
Historia i współczesność zapisane w języku. Pedagogiczne wędrówki po świecie związków frazeologicznych
}

\section{KEYWORDS}

idioms, the history of idioms, idiom modifications, advertising slogans, language education

\begin{abstract}
Kuczak Kinga, Historia i współczesność zapisane w języku. Pedagogiczne wędrówki po świecie związków frazeologicznych [The Past and the Present Inscribed in Language. Educational Endeavours into the World of Idioms]. Kultura - Społeczeństwo - Edukacja nr 2(6) 2014, Poznań 2014, pp. 39-56, Adam Mickiewicz University Press. ISBN 978-83-232-2869-1. ISSN 2300-0422
\end{abstract}

\begin{abstract}
The article attempts to search for continuity between the past and the present inscribed in the language, using selected idioms as examples. The author presents idioms as a linguistic "transmitter" of culture reflecting the experiences of its users. The paper concludes with a few reflections on the role of language education and creating the linguistic awareness of the young generation. The author highlights the need to combine the knowledge of the history of traditional idioms and the knowledge of using new idioms created for advertising and media purposes to shape the attitudes and language activity of young people.
\end{abstract}

\section{Wprowadzenie}

Edward Sapir zauważa, że „zawartość treściowa każdej kultury daje się wyrazić w jej języku i nie ma takiego materiału językowego (...), który by dla użytkowników danego języka nie symbolizował rzeczywistych znaczeń” (Sapir, 1978: 37-38). W tym znaczeniu język stanowi „przekaźnik” szerszej kultury oraz obrazuje doświadczenia jej uczestników. Podobnie Janusz Anusiewicz, Anna Dąbrowska i Michael Fleischer traktują język jako swoiste medium dorobku kulturowego wspólnoty komunikacyjnej. Jest on, zdaniem tych autorów, wyrazem praktyki społecznej tej wspólnoty oraz jej doświadczeń nagromadzonych w ciągu wielu pokoleń. Za jego 
pośrednictwem możliwe jest przekazywanie wartości, ocen i wartościowań oraz norm postępowania, wokół których koncentrują się zachowania, działania, przekonania oraz system etyczno-normatywny danej społeczności (Anusiewicz, Dąbrowska, Fleischer, 2000: 21). Język „odzwierciedla społeczną rzeczywistość oraz wartości kulturowe i tworzy formę społecznych zachowań” (Fleischer, 2000: 47). Można więc powiedzieć, że poszczególne elementy języka, takie jak: gramatyka, słownictwo, frazeologia, składnia, struktura tekstu, semantyka, etymologia, stylistyka, są swoistym odzwierciedleniem kulturowego doświadczenia jednostek i zbiorowości. W szczególny sposób doświadczenie społeczne zapisane zostało w języku za pośrednictwem związków frazeologicznych. Powstają one w wyniku „stabilizacji starych wyrazów w nowej wartości znaczeniowej. (...) Podobnie następuje niekiedy w języku stabilizacja jakiegoś nowego znaczenia całych grup wyrazowych użytych przenośnie w tekście" (Milewski, 1967: 82-83).

Aby o danym połączeniu wyrazowym mówić jako o stałym związku frazeologicznym, musi ono spełniać określone kryteria, na które wskazuje Andrzej Maria Lewicki. Autor ten wyodrębnił cztery zasadnicze elementy decydujące o tym, czy jednostkę leksykalną można uznać za związek frazeologiczny. Należą do nich:

- nieciągłość składu - związek frazeologiczny jest jednostką leksykalną nieciągłą, złożoną z przynajmniej dwóch wyrazów;

- stałość formy - frazeologizm ma stałą formę, a możliwość dokonywania zmian w obrębie związku jest niewielka i ściśle określona, ogranicza się zasadniczo do wymiany form gramatycznych lub leksykalnych (warianty frazeologiczne);

- globalność znaczenia - suma znaczeń składników nie równa się znaczeniu całości;

- utrwalenie w systemie języka - cechą frazeologizmu jest jego odtwarzanie w tekstach na tej samej zasadzie, jak odtwarza się pojedynczy wyraz (za: Podlawska, Świątek-Brzezińska, 2011: 7-8).

\section{Przeszłe i współczesne doświadczenia zawarte w związkach frazeologicznych - analiza na wybranych przykładach}

„Związki frazeologiczne to swoiste dokumenty życia, ponieważ utrwalają i przechowują realia obyczajowo-społeczne minionych epok, mniej lub bardziej odległych, przechowując często dziś już zapomniane elementy kultury materialnej i duchowej" (Podlawska, Świątek-Brzezińska, 2011: 12). Każdy związek frazeolo- 
giczny zakorzeniony jest w tradycji językowej i ma swoje mniej lub bardziej jednoznacznie zdefiniowane źródło; czasem tych źródeł jest kilka. Odzwierciedlają one minione doświadczenia danej społeczności, obrazują też zmiany kulturowe, jakie dokonały się na przestrzeni wieków i dziesięcioleci. Odnoszą się do dawnych, czasem już nieistniejących zawodów, zajęć, wierzeń, zwyczajów. Spora ich grupa wiąże się ze światem roślin, zwierząt, zjawiskami atmosferycznymi, przemianami pór roku, odzwierciedla zależność człowieka od otaczającego go świata przyrody. Takie określenia, jak np. silny jak dąb, trząść się jako osika, stary, ale jary, dobrać się jak $w$ korcu maku, używane są przez współczesnych użytkowników języka w codziennych sytuacjach komunikacyjnych w sposób automatyczny. Dla przykładu odniosę się do ostatniego powiedzenia - dobrać się jak w korcu maku - które aktualnie używane jest w celu określenia osób, które dobrze do siebie pasują, są odpowiednio dobrane. W staropolszczyźnie „korzec” oznaczał duże naczynie o objętości około 100 litrów, służące do przechowywania różnych sypkich produktów, nie tylko maku. Korzec był też jednostką objętości ciał sypkich, zwłaszcza zboża, i w przybliżeniu odpowiadał stu kilogramom. Ta jednostka miary dzieliła się na cztery ćwiartki, zaś każda ćwiartka składała się z ośmiu garncy, garniec miał cztery kwarty, a kwarta cztery kwaterki (szklanki) ${ }^{1}$. Ten dość ogólny opis naczyń i jednocześnie miar objętości pozwala wywnioskować, że korzec jest słuszną metaforą dla sytuacji, w której trudno coś odnaleźć. Podobnie jak obrazowe jest porównanie igły i stogu siana w powiedzeniu: znaleźć igłę w stogu siana.

Język jednak nieustannie się zmienia. Obok utrwalonych już połączeń wyrazowych, które mają swoje historyczne uzasadnienie, pojawiają się innowacje frazeologiczne, rozumiane jako wszelkie odchylenia od normy frazeologicznej opisanej w słownikach frazeologicznych przez językoznawców. Piotr Fliciński, dokonując analizy współczesnej frazeologii, zauważa, że najbardziej rozbudowanym aktualnie dziełem leksykograficznym, w którym można znaleźć wszelkie modyfikacje, jest Wielki Słownik Frazeologiczny Języka Polskiego (Fliciński, 2011: 11). W literaturze językoznawczej wyodrębnia się następujące innowacje:

- rozszerzające - które powstają w wyniku naruszenia łączliwości leksykalnej związku frazeologicznego;

- modyfikujące - które polegają na uzupełnieniu składu leksykalnego związku frazeologicznego nowymi komponentami; 
- analogiczne - które powstają na wzór już istniejących, ale z nowego materiału leksykalnego;

- aluzje frazeologiczne - czyli nawiązania do tradycyjnego związku frazeologicznego;

- defrazeologizacje - polegające na tym, że obok tradycyjnego frazeologizmu, w kontekście ujawniają się też znaczenia potencjalne jego komponentów;

- neosemantyzacje - czyli tworzenie nowego znaczenia na podstawie już istniejącego związku frazeologicznego (Nikołajczuk, 2013: 83-84).

W swoich dalszych rozważaniach przedmiotem analiz uczynię wybrane związki frazeologiczne, które mając odległą tradycję językową, zyskały nowe znaczenie/znaczenia we współczesnym użyciu. Spróbuję również przedstawić wybrane nowe związki frazeologiczne, które weszły do codziennego języka, konkurując $\mathrm{z}$ frazeologizmami od dawna w nim zakorzenionymi. Wiele $\mathrm{z}$ nich ma swoje źródła w sloganach reklamowych, a ich wyróżniającą cechą (w przeciwieństwie do innych stałych połączeń frazeologicznych) jest to, że „powstają na konkretne zamówienie społeczne, handlowe, polityczne” (Müldner-Nieckowski, 2013: 207). Moja analiza stanowi próbę poszukiwania zawartych w języku punktów wspólnych między tradycją a nowoczesnością, czynioną z perspektywy pedagoga, który jest głęboko zainteresowany rozwijaniem świadomości językowej młodego pokolenia, jego wrażliwości na język i umiejętności korzystania z jego obfitego zasobu. Moim zamiarem jest pokazanie, że współcześnie:

- wykorzystuje się historycznie utrwalone połączenia wyrazów w tekstach kultury (reklamach), nadając im nowe znaczenie, nową jakość;

- poprzez tradycyjną formę językową możliwe staje się kreowanie nowych potrzeb jednostek i grup społecznych;

- tworzy się nowe połączenia frazeologiczne poprzez odniesienie do tradycyjnych wartości zakorzenionych w świadomości użytkowników języka;

- kreuje się nowe powiedzenia, które wchodzą na stałe do repertuaru językowego współczesnej polszczyzny.

\section{„Wilczy głód” - „Mały Głód”}

W codziennych sytuacjach komunikacyjnych nierzadko używa się określeń: wilczy głód czy być głodnym jak wilk. Słowo „wilk” ukształtowało się w naszym systemie językowym już w okresie prasłowiańskim (Nalepa, 1972: 449), zaś przywołane tu powiedzenia są utrwalonym w języku przekonaniem przodków, że wilk obdarzony 
jest $\mathrm{z}$ jednej strony łaską niebios, $\mathrm{z}$ drugiej - ogromnym apetytem. Z tego okresu wywodzą się powiedzenia: bierze wilk i liczone owce czy mów wilkowi pacierz, a on woli kozia macierz (Kopaliński, 2012: 467). Wspomniana łaska niebios przejawiała się tym, że głodny wilk miał prawo zjeść wszystko, na co ma ochotę. Mógł zatem, jak wierzono, skonsumować nawet samego czarta. Przy czym „czart to potrawa ciężkostrawna i wilk po niej «biesi się» ${ }^{2}$. Zwierzęciu obdarzonemu taką [diabelską - dop. K.K.] mocą należało wybaczyć porwanie jakiejś marnej kozy” (Kłosiewicz, Kłosiewicz, 2011: 388). Kupcy uważali, że nawet jeżeli wilk porwał im ze stada jedną sztukę, to dzięki jego niezwykłej mocy pozostałe uda im się sprzedać z wyjątkowym zyskiem (Kłosiewicz, Kłosiewicz, 2011: 388). Warto przy tym dodać, że głodny wilk potrafi zjeść jednorazowo nawet do dziesięciu kilogramów mięsa. Tę obserwację wyraża powiedzenie: rzucić się na coś jak wilk/wilki, czyli, dosłownie rzecz ujmując, łapczywie pochłonąć dużą ilość czegoś. W czasach, kiedy wojny niszczyły kraj, polegli na nich ludzie stawali się łatwym pożywieniem padlinożerców, w tym również wilków. Zwierzęta, mając łatwy dostęp do pożywienia, niebezpiecznie szybko się rozmnażały. „Gdy nastawał chwilowy pokój i uprzątano pola bitew, wygłodniałe watahy zagrażały żywym. Prawdziwe i wymyślone opowieści o ludziach pożartych przez wilki powtarzano sobie więc niczym horrory" (Kłosiewicz, Kłosiewicz, 2011: 388). Pozostałością po tych historiach jest powiedzenie: patrzeć wilkiem, czyli odnosić się do kogoś nieufnie, wrogo, patrzeć $\mathrm{z}$ niechęcią, nienawiścią. Wyrażano w ten sposób przekonanie, że lepiej unikać kontaktu z tym zwierzęciem. Już samo o nim wspomnienie, jak sądzono, mogło wywołać nieszczęście. Z tego przekonania wywodzi się określenie: nie wywołuj wilka z lasu - nie mów o rzeczach, zjawiskach zakazanych, groźnych, aby ich w ten sposób nie przywołać i nie urzeczywistnić. Gdy już jednak intruz został wywołany (fakt ten utrwalony został w związku frazeologicznym: o wilku mowa, a wilk tu), trzeba było sobie z nim jakoś poradzić. Wymyślano zatem przeróżne i zmyślne pułapki, których nazwa zachowała się do dziś w języku jako wilczy dół, oraz truciznę, znaną do dziś jako wilcza jagoda. Dla wyjaśnienia dodam, że wilcza jagoda to nazwa krzewu występującego w Polsce na terenach podgórskich, której fioletowo-czarne owoce przypominają owoce borówki, znana jest pod nazwą pokrzyk (łac. Atropa beladonna). Zawiera atropinę, substancję wywołującą halucynacje, a także prowadzącą do blokady mięśni gładkich w organizmie. Do zatrucia wilczą jagodą dochodzi przez zjedzenie owoców lub liści krzewu. Nazwa tej rośliny nawiązuje

\footnotetext{
2 „Biesić się”, czyli wściekać, być podobnym do biesa.
} 
bezpośrednio do zwyczajów żywieniowych wilków, które po zjedzeniu głównego posiłku, na „deser” jadają owoce i runo leśne. Podsunięcie więc owoców wilczej jagody pozwalało pozbyć się drapieżnika ${ }^{3}$. Dodać należy, że roślina ta jest również niebezpieczna dla człowieka, co dodatkowo wzmacniało przekonanie o jej skutecznym działaniu na wspomniane drapieżniki. Na skuteczność tej rośliny wskazywało również powiązanie, w świadomości ludzi, jej właściwości z mocami nadprzyrodzonymi. Wierzono, że jej niezwykłe działanie pomaga wiedźmom latać. Podanie takiego deseru wilkowi, który był niechcianym gościem w pobliżu ludzkich domostwa, musiało być skuteczne.

Aktualnie określenie wilczy apetyt czy wilczy głód zyskało nowe znaczenie dzięki wykorzystaniu go w sloganach reklamujących produkty spożywcze. Dla przykładu, w reklamach i na bilbordach reklamujących znany baton wykorzystano postaci zwierząt, $\mathrm{w}$ tym postać wilka $\mathrm{z}$ ludzką twarzą. W 2008 roku w reklamie telewizyjnej tego produktu posłużono się metaforą zwierzęcego głodu, który domaga się natychmiastowego zaspokojenia. W spocie „głodny chłopak rzuca się na kobietę i wgryza się w ciastka wymalowane na jej spódnicy" (Spychalska, Hołota, 2009: 106), zaspokajając w tej sposób wilczy głód. Ze względu na liczne skargi konsumentów, spot został wycofany. Pojawily się inne, nawiązujące w sposób pośredni do niepohamowanego głodu. Przykładem może być reklama wykorzystująca hasło: Snickers - i jedziesz dalej, która sugeruje, że duży głód można szybko zaspokoić, wystarczy złapać baton (w angielskiej wersji: Grab a Snickers). W innej reklamie również odwołano się pośrednio do wspomnianego związku frazeologicznego. Wilczy głód nie został tu jednak nazwany wprost, zamiast tego posłużono się innym środkiem językowym, a mianowicie neologizmem, który łatwo zapada w pamięć potencjalnych konsumentów i szybko staje się częścią ich języka. W ten sposób możliwe stało się zobrazowanie następującej intencji: człowiek głodny (jak wilk) nie przejawia zwierzęcej agresji, nie atakuje, nie rzuca się na ofiarę, lecz wyraża swoją potrzebę w sposób bardziej wyrafinowany. Uzewnętrznia ją, zachowując się niczym rozkapryszona gwiazda - zaczyna „gwiazdorzyć”. Okiełznać rozkapryszoną gwiazdę pomaga przekąska. Hasło reklamujące produkt stało się elementem kanonu współczesnych frazeologizmów: Zjedz Snickersa, bo jak jesteś głodny [w domyśle - jak wilk; dop. K.K.], to zaczynasz strasznie gwiazdorzyć. Wilczy głód można zatem w określony sposób opanować. Przekąską nie jest jednak tradycyjna wilcza jagoda, lecz nowoczesny sycący baton, po zjedzeniu którego człowiek z powrotem „staje się sobą”.

${ }^{3}$ www.wilki.pl (dostęp: 5.09.2014 r.). 
$\mathrm{W}$ innym spocie reklamowym pojawił się antonim wilczego głodu w postaci Małego głodu, a właściwie Małego Głoda, który uosabia sprytnego, złośliwego, ale jednocześnie zabawnego chochlika: „chowa się w łóżku, wypływa ze ścieków wanny (...). Jego niezaprzeczalnym elementem jest twardość głowy - potrafi on uderzyć w lodówkę z siłą wystarczającą do zrobienia dziury"4. Można się go pozbyć, sięgając po przekąskę. Mały głód, w przeciwieństwie do wilczego głodu, doskonale wpisuje się we współczesny styl życia i dyskurs diety. Jak zauważa Zbyszko Melosik: „można stwierdzić, że niemal każdy jest na diecie bądź na niej był niedawno lub zamierza być wkrótce, a rynek «konsumpcji diety» zalewany jest propozycjami «rewelacyjnych sposobów zrzucania wagi»” (Melosik, 2013: 200). Warto też dodać, że pojęcie wilczy głód zostało aktualnie skojarzone z zaburzeniami w odżywianiu: bulimią i anoreksją. W tym kontekście nabrało jeszcze innego, związanego z chorobą, znaczenia. Bulimia zwana jest żarłocznością psychiczną, wilczym głodem lub wilczym apetytem. Przejawia się, z jednej strony, napadami niekontrolowanego jedzenia, z drugiej zaś - odmową spożywania pokarmów i restrykcyjną dietą. Jak podkreśla Z. Melosik, „niemożliwy jest przy tym całkowicie obojętny, zimny stosunek do jedzenia - w kulturze współczesnej zwiększa się władza jedzenia (zarówno w kontekście konsumpcyjnego «nasycania się», jak i niekiedy masochistycznie stosowanej diety)" (Melosik, 2013: 200). We współczesnej frazeologii wilczy głód został więc zastąpiony przez określenia: odrobina przyjemności, chwila luksusu, lekka przyjemność.

\section{„Kupować koła w worku” - „Twój kot kupowałby Whiskas”}

Bohaterem wielu związków frazeologicznych jest kot, co nie może dziwić, zważywszy na bliskie kontakty człowieka $\mathrm{z}$ tym zwierzęciem zapoczątkowane już w starożytności. Jak podają źródła historyczne, kot został udomowiony około 4000 lat p.n.e. w Nubii, do Egiptu sprowadzono go około 2000 lat p.n.e. Tam był hodowany jako cenne, otoczone czcią zwierzę domowe. Swoją uprzywilejowaną pozycję stracił w średniowieczu, kiedy stał się symbolem ciemności, grzechu, chytrości i zdrady. Kot uważany był wówczas za najbardziej chytre (oprócz lisa) zwierzę. Jednak mimo tych negatywnych cech, równocześnie wzbudzał podziw i strach. Szczególny respekt budziły kocie oczy - świecące w ciemności, a także jego niezależne usposobienie, zwyczaj nocnego życia i bezszelestnego poruszania się. Od wieków wiado-

\footnotetext{
${ }^{4}$ www.nonsensopedia.wika.com (dostęp: 5.09.2014 r.).
} 
mo też, że: kot chadza swoimi ścieżkami. Ze względu na te przymioty uważano, że zwierzę to ma magiczną moc: „koci ogon, pazur, kocie oko, serce i kocia głowa wchodziły w skład leków i substancji magicznych” (Ogrodowska, 2001: 90). Koty były więc cennym towarem, nabywanym ze względu na wymienione wyżej właściwości. Z XIII wieku pochodzi powiedzenie: kupować kota w worku, czyli kupować coś bez sprawdzenia, co się rzeczywiście kupuje. Etymologia tego wyrażenia nie wiąże się jednak bezpośrednio z dokonywaniem zakupu tego właśnie zwierzęcia. Większość produktów kupowało się wówczas w workach plecionych $\mathrm{z}$ konopi. W języku rosyjskim funkcjonują określenia o zbliżonym znaczeniu: nie kupuje się konia na ślepo oraz tylko jajkami handluje się na ślepo (Kopaliński, 2006: 11). W worku można było kupić prosię czy zająca, i pierwotnie to powiedzenie dotyczyło nabywania właśnie tych zwierząt bez należytej uwagi. Inny trop etymologiczny sięga do tradycji łowieckiej. W gwarze łowieckiej zająca nazywano kotem. Może to wskazywać na fakt, że kiedy kupuje się w pośpiechu, można nabyć zepsutego, nieświeżego zająca (Głowińska, 2008: 175) . Inna wersja podaje, że frazeologizm ten wywodzi się ze zwyczaju wykorzystywania kocich skór na ubrania, obicia, dywany itp. Właściciele kotów, aby uchronić je przed złapaniem przez hycla i przerobieniem na produkt handlowy, wypalali im na skórze znamiona, co obniżało wartość rynkową skóry. Kupienie kociej skóry bez należytego sprawdzenia jej jakości stało się źródłem wspomnianego związku frazeologicznego ${ }^{6}$. Interesującym dla badacza powiedzeniem odnoszącym się do tego czworonoga jest ganiaćllatać jak kot $z$ pęcherzem, czyli ruszać się nerwowo, przemieszczać się z miejsca na miejsce w sposób gwałtowny. Katarzyna Głowińska informuje, iż w przeszłości popularna była zabawa, która polegała na tym, że kotu do ogona przywiązywano wysuszony rybi pęcherz. Jego wnętrze wypełniano grochem, który wydawał dźwięki przy każdym ruchu zwierzęcia próbującego w panice uciec przed hałasującym przedmiotem (Głowińska, 2008: 175). Nie mogło jednak tego zrobić, gdyż pęcherz rybi był przywiązany, a im bardziej kot próbował uciec, tym dźwięk, który wydawał pęcherz, był głośniejszy i bardziej dokuczliwy.

Z kotem związana była też kara wymierzana za drobne wykroczenia przeciw „obyczajowości publicznej”, zwana ciagnięciem kota. Polegała ona na tym, że kara-

\footnotetext{
${ }^{5} \mathrm{Na}$ temat źródeł innych związków frazeologicznych piszę też w książce Świat związków frazeologicznych $w$ języku dziecka. Inspiracje teoretyczne - badania - implikacje praktyczne, Wydawnictwo Naukowe UAM, Poznań 2014, oraz $\mathrm{w}$ artykule Językowy obraz rodziny $w$ zwiąkach frazeologicznych i interpretacjach dziecięcych, „Wychowanie w Przedszkolu” 2014, nr 6.

${ }^{6}$ www.edusens.pl (dostęp: 12.10.2014 r.).
} 
nego wiązano do jednego końca sznura, do drugiego zaś przywiązywany był kot. Między jednym a drugim końcem sznura znajdowała się błotnista sadzawka. Zawody polegały na przeciągnięciu przeciwnika przez sadzawkę. Wygrywał je, oczywiście, kot, który miał wielu pomocników. „Egzekucja ta przynosiła więcej śmiechu niż bólu, ale dyshonor był znaczny” (Kłosiewicz, Kłosiewicz, 2011: 361). Z opisaną tu zabawą może zatem wiązać się powiedzenie, iż kot zawsze spada na cztery łapy, bo przecież kot wychodził z tej zabawy bez uszczerbku. Jerzy Bralczyk, odnosząc się do wspomnianego powiedzenia, wyjaśnia, iż „ci, co przyrównani są do trudno uszkadzanych czy uszkadzających się kotów, cieszyć się mogą naszym względnym podziwem, ale nie bezwzględną sympatią: z każdej opresji wyjdą cało, a nawet, choć o tym się już nie mówi, z jakimiś korzyściami” (Bralczyk, 2009: 113). Ten związek frazeologiczny zyskał aktualnie nowe znaczenie dzięki modyfikacji frazeologicznej wykorzystanej w reklamie pożywienia dla kota, która ma skłonić właścicieli kotów do (jeszcze) większej troski o swoich czworonożnych podopiecznych. Aktualna modyfikacja brzmi: Aby twój kot zawsze spadał na cztery łapy. Można tu zauważyć, że „slogan korzysta z zasobu motywów utrwalonych w kulturze, aby przekazać informację o produkcie" (Spychalska, Hołota, 2009: 60) i zachęcić do jego nabycia. Wszyscy doskonale rozumiemy sens tego powiedzenia, zdajemy sobie też sprawę, że twórcy sloganu „puszczają do odbiorców oko”. Nie można przecież pozwolić, by kot nie miał szansy spaść na cztery łapy.

Powiedzenie, od którego rozpoczęłam swoje rozważania - kupować kota $w$ wor$k u$ - zyskało aktualnie nowe znaczenie (znaczenia), podobnie jak wcześniej omawiany związek frazeologiczny wilczy głód. W związku z powszechnym dostępem do Internetu i możliwością dokonywania zakupów za jego pośrednictwem, powiedzenie to stało się ponownie aktualne. Posłużono się nim jako hasłem reklamowym programu bezpiecznych zakupów - www.niekupujkotawworku.pl. Producenci wykorzystują ten utrwalony w języku i łatwy do zidentyfikowania związek też w inny sposób, zachęcając klientów do przetestowania wyprodukowanych przez nich produktów: Weź na próbę, nie kupuj kota w worku $u^{7}$. Wspomniany frazeologizm wykorzystywany jest nie tylko w reklamie, ale stał się również popularnym hasłem w nagłówkach gazet. Użyto go na przykład do sformułowania oceny rządowego elementarza. W „Gazecie Wyborczej” z dnia 30 lipca 2014 roku zamieszczono następujący nagłówek: „Odrzucają rządowy elementarz. Nie chcą kupować kota w worku" ${ }^{8}$, co oznacza, że nie podjęto decyzji o zakupie produktu wątpliwej

\footnotetext{
${ }^{7}$ www.archiwumchaosu.pl (dostęp: 12.10.2014 r.).

${ }^{8}$ www.wyborcza.pl (dostęp: 12.10.2014 r.).
} 
jakości. „Ekspres Bydgoski” z 13 czerwca 2005 roku zaproponował nagłówek „Nie kupować kota w worku" dla artykułu na temat walki szkół policealnych o kandydatów9. Także „Tygodnik Nadwiślański” z dnia 28 marca 2013 roku wykorzystał ten związek w tytule tekstu: „Burmistrz nie chce kupować kota w worku” ${ }^{10}$. „The Times Polska” proponuje z kolei pod hasłem „Nie kupujesz kota w worku” artykuł na temat obrotu samochodami z drugiej rę $\mathrm{ki}^{11}$. Na podstawie tej krótkiej analizy można stwierdzić, że powiedzenie kupować kota $w$ worku jest powszechnie używane w różnych współczesnych modyfikacjach, pozwala też przekazać zupełnie nowe znaczenia. Kot w worku symbolizuje brak bezpieczeństwa np. w przypadku zakupów dokonywanych w Internecie.

Uzupełniając analizy związków frazeologicznych odnoszących się do kota, warto dodać, że jest on bohaterem innych, wykreowanych dla potrzeby reklam powiedzeń, które weszły na do kanonu współczesnego języka. Jednym z nich jest funkcjonujące w wielu językach hasło: Twój kot kupowałby Whiskas ${ }^{12}$. Marta Spychalska i Marcin Hołota zauważają, że powiedzenie to jest nie tylko doskonale rozpoznawane i kojarzone $\mathrm{z}$ określonym produktem, ale też $\mathrm{w}$ różny sposób parafrazowane. Pojawiają się zatem takie powiedzenia, jak: Mój kot kupowałby Kitkat czy Twój kot kupowałby whisky (Spychalska, Hołota, 2009: 182-183). Na przykładzie tego porzekadła można dostrzec zmianę w języku - za jego pośrednictwem wyrażany jest stosunek człowieka do kota. Kot nie jest już nabywanym towarem, obiektem czarów lub zabaw, stał się osobą, konsumentem. Fakt zmiany w postrzeganiu tego zwierzęcia odzwierciedla kolejny popularny slogan reklamujący karmę: Sa powody do mruczenia. M. Spychała i M. Hołota interpretują go w następujący sposób: „liczy się to, co kota uszczęśliwia i co odpowiada jego upodobaniom, nie zaś to, co właściciel uważa za odpowiednie" (Spychała, Hołota, 2009: 158) Mruczenie jest przecież łatwo rozpoznawalna oznaką dobrego nastroju kota. Zatem karma, która wywołuje mruczenie, musi być wyjątkową karmą. Slogan ten doskonale oddaje współczesną ideologię przyjemności - nie tylko tej będącej udziałem człowieka, ale też otaczających go czworonogów, którym przypisuje się cechy ludzkie. Kot (pies), podobnie jak człowiek, zasługuje na przyjemność. Dążenie do przyjemności uzyskanej dzięki kupowaniu znalazło swoje odzwierciedlenie w języ-

\footnotetext{
${ }^{9}$ www.ekspres.bydgoski.pl (dostęp: 12.10.2014 r.).

${ }^{10}$ www.tyna.info.pl (dostęp: 12.10.2014 r.).

${ }^{11}$ www.polskatimes.pl (dostęp: 12.10.2014 r.).

${ }^{12}$ Zdanie to zostało pierwszy raz sformułowane w 1963 roku na początku kampanii reklamowej karmy dla kotów.
} 
ku i frazeologii typu: natychmiastowa przyjemność, euforia supermarketu (Melosik, 2014: 162-163). Współcześnie nie kupuje się już kota $w$ worku - dokonuje się udanych zakupów, by być na topie (Melosik, 2014: 162-163). Wymienione tu dla przykładu, za Z. Melosikiem, związki frazeologiczne odzwierciedlają idee maksymalizacji życia i rywalizacji o to, co najlepsze. Przejawem tej orientacji są frazeologizmy typu polecany przez profesjonalistów, używane w reklamach karmy dla zwierząt. Niosą one następujące przesłanie: ponieważ ty jesteś wyjątkowy, również twój kot (pies) jest wyjątkowy; wybieraj zatem dla niego to, co polecają profesjonaliści, gdyż zwykłym właścicielom zwierząt brakuje kompetencji i doświadczenia. Tylko wówczas twój ulubieniec będzie godnie ciebie reprezentował, nie jest przecież przysłowiowym kotem w worku.

\section{„Nawarzyć piwa” - „Piwo, którego nikt nie spasteryzował”}

Słowo „piwo” w języku polskim wywodzi się od czasownika „pić” i zostało utworzone przez dodanie przyrostka „-wo”, co z perspektywy słowotwórczej oznacza: „to, co jest pite” (Podracki, 1994: 94). Piwo uważane jest za jeden z najstarszych napojów świata. Pili je już starożytni Sumerowie i nazywali sikaru. Napój ten znany był w rejonach zamieszkałych przez Słowian i Germanów. Gall Anonim w swojej kronice przytaczał zapiski Piasta Kołodzieja o następującej treści: „Mamci ja naczyńko warzonego piwa, com je przysposobił na postrzyżyny mego jedynaka” (za: Kłosiewcz, Kłosiewcz, 2011: 132). Jerzy Bralczyk podkreśla, że „kiedyś Prasłowianie pili ol (jak dziś na przykład Szwedzi) - i to było piwo, ol był piwem” (Bralczyk, 2014: 134). W średniowieczu opactwa i klasztory stały się ośrodkami piwowarstwa. Nic więc dziwnego, że napój ten wspominał na łożu śmierci Klemens VIII, modląc się do „Pivy” modlitwą, która brzmiała następująco: „santa Piva, ora pro eo...” (Bralczyk, 2014: 134); w innej wersji: „O Santa pivia di Polonia! O Santa piva di Warka” (Kłosiewcz, Kłosiewcz, 2011: 133). Jedno ze starszych polskich przysłów również odnosi się do tego napoju. Powiedzenie „Dum bibo piwo, stat mihi kolano krzywo", znalezione na marginesie XV wiecznego rękopisu łacińskiego, mówi o tym, że „jak piję piwo, to stoi mi kolano krzywo” (Kłosińska, 2011: 35). Piwo pito powszechnie, tym bardziej że spożywanie nieprzegotowanej wody wiązało się z ryzykiem chorób, w tym najbardziej niebezpiecznej, zwanej „zarazą”. Piwo było więc napojem niemalże uświęconym: „Wiele klasztorów, zamków i bogatych domów miało własne browary, bo w krajach północnych piwo uważano 
za towar pierwszej potrzeby" (Kopaliński, 2006: 243). Proces przygotowywania napoju polegał na obróbce termicznej zboża z dodatkiem drożdży, zwanej warzeniem. Znano też udoskonaloną metodę przyrządzania tego napoju ze słodu, który był uzyskiwany dzięki namoczeniu ziaren aż do ich skiełkowania, co powodowało zmianę zawartej w nich części skrobi w cukier. Tak uzyskany słód następnie mielono i zalewano wrzątkiem (Hensel, 1972: 294). Ważnym składnikiem napoju już od IX wieku był chmiel, którego właściwości przeciwdrobnoustrojowe i konserwujące doceniono już wówczas. Ceniono też jego działanie lecznicze i polecano napój jako lek na rozmaite dolegliwości. Jakub Kazimierz Haur zalecał damom picie piwa na poprawienie wyglądu cery: „Damom także czerstwą, rumianą i glancowną sprawuje cerę, gdy piwo grzane $\mathrm{z}$ kminkiem albo tłuczonym koprem włoskim, z masłem na czczo i na noc zażyją" ${ }^{13}$. Piwo w formie polewki piwnej z dodatkiem jaj, cukru, szafranu i innych przypraw uważano za produkt dietetyczny i podawano na śniadanie.

Z faktem przygotowywania wspomnianego napoju wiąże się popularny do dziś frazeologizm nawarzyć piwa, czyli narobić sobie lub komuś kłopotów, zmartwienia, zamieszania. Funkcjonuje też inne powiedzenie odwołujące się do warzenia piwa, a mianowicie: wypić piwo, które się nawarzyło, czyli ponieść konsekwencje własnych czynów. Można zauważyć, że w tradycji językowej nadmierna ilość tego napoju skojarzona została z kłopotami, negatywnymi konsekwencjami, co znalazło swoje odzwierciedlenie $\mathrm{w}$ przysłowiu: od piwa się głowa kiwa. Dla odmiany, w świadomości społecznej jego niewielka ilość symbolizuje drobnostkę, jak w powiedzeniu: małe piwo. Słowniki frazeologiczne wskazują, iż małe piwo to tyle, co drobiazg, szczegól, coś nieistotnego, niegodnego uwagi, lub coś łatwego. Widać więc, że w tradycji zapisanej w języku przygotowywanie i spożywanie tego napoju wymaga umiaru.

Współczesny język ukształtował wiele powiedzeń odnoszących się do wspomnianego napoju. We współczesnej frazeologii, kreowanej przez wirtualne media i twórców reklam, pojawiają się określenia mające w sposób bezpośredni podkreślić wyjątkową jakość tego produktu: piwo niepasteryzowane czy piwo, którego nikt nie spasteryzowat. Szczególnie to drugie wykorzystuje pojęcie pasteryzacji w sposób niedosłowny. Pasteryzacja nie oznacza tu bowiem „niszczenia drobnoustrojów w produktach spożywczych przez kilkakrotne podgrzanie do temperatury między sześćdziesiąt a dziewięćdziesiąt stopni” (Drabik, Kubiak-Sokół, Sobol, Wiśniakow-

${ }^{13}$ www.wilanow-palac.pl (dostęp: 5.10.2014 r.). 
ska, 2011: 624), ale sugeruje zniszczenie, zepsucie produktu. Samo pojęcie pasteryzacji nabiera zatem innego znaczenia.

Znaczna część sloganów reklamowych odnosi się do tradycyjnego procesu przygotowywania napoju, np.: tutaj warzq się doznania, długo warzone, warzone według tradycyjnej receptury czy $z$ otwartych kadzi, jak kiedyś. Zastosowano tu prostą zasadę, o której wspomina J. Bralczyk: „frazeologia to podstawa sloganu, który działa, gdy jest oryginalny, ale działa też, gdy wywołuje poczucie znajomości. Tworzenie nowej i korzystanie ze starej frazeologii w niewielu sytuacjach językowych funkcjonuje tak dobrze, jak w sytuacjach reklamowych” (Bralczyk, 2004: 82). Odwołanie się do tradycyjnej receptury i otwartej kadzi ma przywołać skojarzenie $\mathrm{z}$ najwyższą jakością oraz z właściwym czasem przygotowania, jak w sloganie: $w y$ trawny smak rodzi się z czasem. Tego typu frazeologia ma uzmysłowić odbiorcom-konsumentom wagę, jaką przywiązują twórcy (coraz częściej sięga się do pojęcia: piwowarzy) napoju do właściwego jego przygotowania. Wynikiem takiego postępowania jest wysokiej klasy napój. Na tym przykładzie widać wyraźnie, że współczesna frazeologia reklamowa odwołuje się do wizji współczesnego życia: wyjątkowej jakości, najlepszej jakości. Jakość stała się synonimem luksusu.

\section{Znaczenie edukacji - w stronę rozwijania świadomości językowej}

Obecność związków frazeologicznych w języku wzbogaca go, czyni wypowiedź/ komunikat bardziej interesującym. Pozwala na dobitne, bardziej precyzyjne wyrażenie myśli poprzez wykorzystanie ładunku emocjonalnego, który zawiera frazeologizm. Dla przykładu posłużę się powiedzeniem diabli wzięli, które oznacza, że coś zostało bezpowrotnie utracone, coś przepadło. Jednak ładunek emocjonalny komunikatu, intencja nadawcy wyrażona przy użyciu wspomnianego powyżej związku frazeologicznego np. w sposób następujący: „Diabli wzięli moje plany wakacyjne, muszę zostać w pracy”, nadaje wypowiedzi zupełnie inny charakter niż w przypadku powiedzenia: „Moje plany wakacyjne przepadły, muszę zostać w pracy”. Sięgnięcie do związku frazeologicznego jako środka stylistycznego pozwala przekazać emocje, ale też daje możliwość wyrażenia humoru, sarkazmu, przekazania treści w sposób niebezpośredni, np. „Złego diabli nie biorą, wyszedłem z tego cało". Intencja nadawcy przedstawiona jest nie tylko bardziej dobitnie, ale zawiera też szczególny koloryt. Posługiwanie się związkami frazeologicznymi wymaga jednak świadomości językowej, wrażliwości na język i wiedzy na temat tego, jakie 
znaczenia można wyrazić za ich pośrednictwem oraz w jakiej sytuacji sięgnąć po określone powiedzenie.

Współcześnie zaobserwować można dwa zjawiska językowe:

- Z jednej strony dużą aktywność, twórczość frazeologiczną, modyfikacje frazeologiczne, korzystanie z utrwalonych w świadomości społecznej związków frazeologicznych (na ten aspekt starałam się zwrócić uwagę podczas wcześniejszych rozważań) przez media, także papierowe, w tym prasę codzienną oraz twórców reklam. Jan Miodek, oceniając ten aspekt współczesnej twórczości frazeologicznej, zauważa: „nie bójmy się przyznać, że do rejestru skrzydlatych słów dołączyła reklama. Sam łapię się na tym, że jeśli ktoś mi snuje jakieś wizje, mam mu ochotę powiedzieć: to nie wizja, to Vizir. Jeśli w domu po jakimś zamieszaniu nagle się wszystko uspokaja, mam ochotę powiedzieć: jest Leżajsk, jest dobrze" (Miodek, 2014: 91). To stwierdzenie uzmysławia, jak bardzo frazeologia kreowana przez media weszła do powszechnego użycia.

- Z drugiej strony wskazuje się na ubożenie współczesnego języka polskiego, zasypywanie go anglikanizmami, „słowami-wytrychami”, wulgaryzmami. Ten aspekt Joanna Kulmowa opisuje w następujący sposób:

Ojczyzna Polszczyzna wymyka się nam z kretesem. Trudno przytrzymać ją za podmiot i orzeczenie, skoro ukazuje się nam tylko wyrywkowo jak uśmiech Kota z Cheshire. Odeszłabym i ja za topniejącym uśmiechem, gdyby nie to, że pojawił się nam na buzi. Na buzi wszechobecnej. Ksiądz Piotr w Dziadach zastępował buzię obliczem:

Panie! Czymże ja jestem przed Twoim obliczem? -

Prochem i niczem;

Oblicza już nie ma.

Nie ma lic.

Twarzy.

Gęby.

Pyska.

Mordy.

Nawet fizjonomii.

Jest BUZIA.

Dawniej bywała jeno dla maluchów. Albo w porywach chamstwa: „Chcesz dostać po buzi?”.

Dzisiaj wyparła nawet policzki i usta, ba, wargi.

Zdrobniało nam wszystko na amen.

Boziu! Czymże ja jestem przed Twoją buziuchną? -

Nicość i próchno (Kulmowa, 2014:. 131). 
W tym kontekście zubożenia języka, powszechnych anglikanizmów, „dominującego luzu i potoczności w wulgarnej postaci” (Puzynina, 2011: 114), ale też nowych frazeologizmów „zapadających w świadomość społeczną”, edukacja językowa powinna być realizowana dwutorowo:

- Poprzez odwołanie do tradycji językowej i umożliwienie młodemu pokoleniu dostrzeżenia bogactwa językowego zawartego (między innymi) w związkach frazeologicznych, zrozumienia ich znaczenia dzięki możliwości sięgnięcia do ich źródeł, poznania historii. Bo przecież „każde z nowych pokoleń, które wchodzi w teraźniejszość, nie zaczyna wszystkiego od nowa, jest spadkobiercą wielkiego zasobu dóbr materialnych, idei, sposobów życia, wartości duchowych. (...) Nie zawsze jest to dziedziczenie bezpośrednie z pokolenia na pokolenie. Nierzadko zdarza się, że elementy z najdawniejszej historii zajmują ważniejsze miejsce niż te z bezpośredniej bliskości czasowej" (za: Ziemski, 2002: 33). Ważnym elementem edukacji językowej jest odkrycie przez młodego człowieka związków frazeologicznych, które powstały w różnym czasie, np. mają swoje mitologiczne, ludowe, rycerskie czy szlacheckie źródła, wiążą się ze światem sportu, literatury lub polityki. Istotne jest odszukanie ich pierwotnego znaczenia i zrozumienie, że wiele $\mathrm{z}$ funkcjonujących w języku powiedzeń oznacza aktualnie coś zupełnie innego, niż oznaczało pierwotnie, a każdy związek frazeologiczny ma swoją historię i podlega zmianom i modyfikacjom, tak jak zmienia się świat i ludzie.

- Poprzez uzmysłowienie, że język, jako narzędzie, służy do przekazywania znaczeń. Natomiast słowo, powiedzenie, wypowiedź służy nie tylko wyrażaniu wiedzy na temat rzeczywistości, informowaniu i opisywaniu świata, porządkowaniu informacji, ale też za jego pośrednictwem możliwe jest kształtowanie określonych postaw ludzi, wpływanie na ich zachowania i decyzje, na ich sposób myślenia i działania. W ten sposób język wykorzystywany jest w sloganach reklamowych. Podstawowym typem komunikatu, jaki wykorzystuje reklama, jest komunikat perswazyjny. „Zasadniczą właściwością komunikowania perswazyjnego jest takie oddziaływanie na odbiorcę, aby nakłonić go do akceptacji oraz zaadaptowania nowych zachowań i postaw zgodnych z intencją nadawcy” (Dobek-Ostrowska, 2007: 32-33). Powszechność sloganów reklamowych, celowy dobór używanych w nich słów, zwrotów, by przyciągnąć i zatrzymać uwagę odbiorców - wszystko to sprawia, że stają się one dla dzieci i młodzieży atrakcyjną formą językowego wyrażania rzeczywistości. „Literatura przestała być wspólnym kodem, za to «świstak, który siedzi 
i zawija w te sreberka...» i tym podobne - jak najbardziej" (Markowski, 2014, s. 93). Slogany sięgające do zakorzenionych w świadomości użytkowników języka połączeń frazeologicznych (np. fortuna kołem się toczy, fortuna się toczy owocem), tworzące nowe związki wyrazowe (np. bielszy odcień bieli), bawiące się formą językową (np. rano kawka, wieczorem Żubr), „igrające” z normą językową (np. metoda na Głoda) - mogą stać się atrakcyjnym materiałem dla potrzeb edukacji językowej. Jerzy Sosnowski w swojej rozmowie z Jerzym Bralczykiem, Janem Miodkiem i Andrzejem Markowskim zauważył, że reklama ożywiła naszą wyobraźnię językową (2014: 93). Z całą pewnością ożywiła też wyobraźnię językową młodego pokolenia. Ten niewątpliwy zasób warto wykorzystać w działalności edukacyjnej.

\section{Literatura}

Anusiewicz J., Dąbrowska A., Fleischer M. (2000). Językowy obraz świata i kultura. Projekt koncepcji badawczej. „Acta Universitatis Wratisleviensis”, t. 13, s. 11-44.

Bralczyk J. (2004). Język na sprzedaż, czyli o tym, jak język służy reklamie i jak reklama używa języka. Gdańsk.

Bralczyk J. (2009). Porzekadła na każdy dzień. Warszawa.

Bralczyk (2014). Jeść!!! Olszanica.

Bralczyk J., Miodek J., Markowski A. w rozmowie z Jerzym Sosnowskim (2014). Wszystko zależy od przyimka. Warszawa.

Dobek-Ostrowska B. (2007). Podstawy komunikowania społecznego. Wrocław.

Drabik L., Kubiak-Sokół A., Sobol E., Wiśniakowska A. (2011). Słownik Języka Polskiego. Warszawa.

Fleischer M. (2000). Obraz świata. Ujęcie z punktu widzenia teorii systemów i konstruktywizmu. „Acta Universitatis Wratislaviensis", t. 13, s. 45-71.

Fliciński P (2011). Innowacje frazeologiczne w świetle dostępnych frazeologizmów. „Poznańskie Studia Polonistyczne", nr 18(38), s. 9-19.

Głowińska K. (2008). Słownik frazeologiczny. Suchy Las.

Kłosiewicz S., Kłosiewicz O. (2011). Przyroda w polskiej tradycji. Warszawa.

Kłosińska K. (2011). Słownik przysłów. Przysłownik. Poznań.

Kopaliński W. (2006). Koty w worku, czyli z dziejów pojęć i rzeczy. Warszawa.

Kopaliński W. (2012). Stownik symboli. Warszawa.

Kulmowa J. (2014). Oblicze. [W:] Zapomniane słowa. Red. M. Budzińska. Wołowiec, s. 131.

Leciejewicz L. (red.) (1972). Mały słownik kultury dawnych Słowian. Warszawa.

Melosik Z. (2013). Kultura popularna i tożsamość młodzieży. W niewoli władzy i wolności. Kraków.

Milewski T. (1967). Językoznawstwo. Warszawa.

Müldner-Nieckowski P. (2007). Frazeologia poszerzona. Warszawa.

Nalepa J. (1972). Charakterystyka językowa dawnej słowiańszczyzny. [W:] Mały słownik kultury dawnych Stowian. Red. L. Leciejewicz. Warszawa, s. 499. 
Nikołajczuk K. (2013). Kompetencja rodzimych użytkowników polszczyzny oraz obcokrajowców (Ukraińców) w zakresie stosowania polskiej frazeologii temporalnej. „Acta Universitas Lodzianensis", nr 20, s. 83-92.

Ogrodowska B. (2001). Zwyczaje, obrzędy i tradycje w Polsce. Warszawa.

Podlawska D., Świątek-Brzezińska M. (2011). Słownik frazeologiczny języka polskiego. Warszawa Bielsko-Biała.

Podracki J. (1994). Świat ludzi, rzeczy i słów. Pogadanki o języku i kulturze. Radom.

Podracki J. (2000). Pułapki językowe - w szkole i nie tylko... Warszawa.

Puzynina J. (2011). Kultura Słowa. Łask.

Sapir E. (1978). Kultura, język, osobowość. Wybrane eseje, przeł. B. Stanosz, R. Zimand. Warszawa.

Spychalska M., Hołota M. (2009). Słownik sloganów reklamowych. Warszawa.

Ziemski F. (2002). Istota i ewolucja pojęcia tradycji - dzieci i młodzież w świecie tradycji. [W:] B. Dymara, W. Korzeniowska, F. Ziemski, Dziecko w świecie tradycji. Kraków.

\section{Źródła internetowe:}

www.archiwumchaosu.pl (dostęp: 12.10.2014 r.).

www.edusens.pl (dostęp: 12.10.2014 r.).

www.ekspres.bydgoski.pl (dostęp: 12.10.2014 r.).

www.kurpie.com.pl (dostęp: 7.09.2014 r.).

www.niekupujkotawworku.pl (dostęp: 12.10.2014 r.).

www.nonsensopedia.wika.com (dostęp: 5.09.2014 r.).

www.polskatimes.pl (dostęp: 12.10.2014 r.).

www.tyna.info.pl (dostęp: 12.10.2014 r.).

www.wilki.pl (dostęp: 5.09.2014 r.).

www.wyborcza.pl (dostęp: 12.10.2014 r.).

\section{The Past and the Present Inscribed in Language. Educational Endeavours into the World of Idioms}

\section{Summary}

The article attempts to search for continuity between the past and the present inscribed in the language, using selected idioms as examples. The author presents idioms as a linguistic "transmitter" of culture reflecting the experiences of its users. In the first part of her reflections she notes after S. Milewski that individual elements of language such as grammar, vocabulary, phraseology, syntax, text structure, semantics, etymology and style, in a way reflect the cultural experience of individuals and communities. She also underlines the fact that idioms are a unique way of inscribing the social experience in language, since they may be said to document life: they preserve and carry on the social reality of more and less distant past and they often keep forgotten elements of material and spiritual culture. Because language is constantly evolving, phraseological innovations, understood as all deviations from the phraseological norm described in phraseological dictionaries by linguists, appear 
alongside fixed word phrases. Based on the abovementioned assumptions, the article attempts to show (using selected idioms as examples) that:

- contemporary texts of culture (advertisements, commercials) use historically set lexical bundles, giving them a new quality and meaning;

- it is possible, through the traditional linguistic norm, to create new needs of individuals and social groups;

- new phraseological bundles are coined based on references to traditional values rooted in language users' consciousness;

- new sayings are created, which are then incorporated into the contemporary Polish vocabulary.

Author presented her analyses of the past and the present in light of idioms in the following frameworks:

- from the saying "wilczy głód" (literally: "wolf s hunger", an old saying meaning: great hunger) to the saying "mały głód" (literally: "little hunger", from a popular Polish commercial);

- from the saying "kupować kota w worku" (literally: "to buy a cat in a sack", an old saying meaning "to buy a pig in a sack") to "cats would buy Whiskas (if they could)"

- from the saying "nawarzyć piwa" (literally: "brew some beer", meaning "to get oneself in trouble") to the saying "piwo, którego nikt nie spasteryzował" (literally: "beer that hasn't been pasteurized", from recently popular Polish commercials of unpasteurized beer).

The paper concludes with a few reflections on the role of language education and creating the linguistic awareness of the young generation. The author highlights the need to combine the knowledge of the history of traditional idioms and the knowledge of using new idioms created for advertising and media purposes to shape the attitudes and language activity of young people. 